\title{
Mis värvi on muinasjutt?
}

\author{
Kärri Toomeos-Orglaan
}

Teesid: Seda, milline roll on muinasjutus värvusel, ei pruugi kohe esimesel silmapilgul märgata. On arvatud, et sellel ei ole muud funktsiooni, kui kirjeldada objekti välimust. Teised jällegi käsitlevad värvust sümbolite süsteemina, mis kätkeb endas pärimuskandjate usundilist maailmapilti ning väärtushinnanguid.

Artiklis uurin lähemalt värvuste esinemist eesti imemuinasjuttudes ning seda, milliseid assotsiatsioone nende abil luuakse. Värvitemaatikaga haakub samuti kehalisuse aspekt, mis loob kriitilise vaatepunkti naise kujutamisele muinasjutus.

Märksõnad: ilu, imemuinasjutt, kehalisus, värvisümboolika

\section{Sissejuhatus}

Muinasjutu-uurija Max Lüthi sõnul ei ole värvusel muinasjutu üldises süžeelises plaanis erilist tähtsust. Isikute või objektide kirjeldamine mõne värvuse abil loob kontrasti muidu ilma värvita jutumaailmas, värv aitab neid ülejäänutest eristada ning esile tõsta. Lüthi on seisukohal, et värvus võib jutus küll esineda, kuid selle puudumine ei too kaasa sisulisi muutusi. Võib isegi öelda, et teatud mõttes valitseb muinasjutus ilma värvita olek. (Lüthi 1982: 28)

Idee muinasjutust kui ilma värvita maailmast on intrigeeriv. Üldiselt võib Lüthiga nõustuda, vaatleb ta ju muinasjuttu kui žanri laiemalt, tuues välja kõige üldisemad jooned, mis muinasjutu tegevustikku iseloomustavad. Siiski ärgitab tema väide järele uurima, millisel positsioonil värvus muinasjutus ikkagi on. Kas tegemist on üksnes objekti kirjeldusega või kannab see endas veel mingisuguseid tähenduskihte.

Varem pöörati värvusele muinasjutu kontekstis vähe tähelepanu, nii käsitleb ka Heda Jason värvust vaid tegelasi ja objekte kirjeldava epiteedina (Jason 1977: 172). Alles viimastel kümnenditel võib näha värvitemaatikaga seotud muutusi: värvust on hakatud vaatlema kui sümbolit ja semiootilist märki, mille 
abil kirjeldatakse nii tegelaste olemust kui ka ühiskonnas levinud väärtushinnanguid näiteks soorollidega seoses (vt Hurley 2005; Vaz da Silva 2007; Agirel 2009; Jorgensen 2013b). Värvi teemaga seoses kerkib esile ka kehalisuse aspekt, mis avaldub kõige selgemalt muinasjututegelaste välimuse kirjeldustes. Sellele on tähelepanu juhtinud Jeana Jorgensen, kelle uurimistöö keskmes on inimkeha kirjeldamisel kasutatav sõnavara (nimi- ja omadussõnad) muinasjutužanris. Kehalisus väljendub muinasjutus sageli just värvuse kaudu, mis on ennekõike seotud nahaga (skin description) (Jorgensen 2013a: 50).

Kehalisuse aspektile tasub tähelepanu pöörata ka eesti ainese puhul ja mitte ainult muinasjuttudes. Näiteks mõistatustes on värvus üks olulisemaid lahendobjekti välimust kirjeldavaid tunnuseid (vt Voolaid 2016) ning regilaulus on noort naist nimetatud selliste poeetiliste sünonüümidega nagu valgepea, kuldakaela, punapale (vt Roll 1985: 41; Peegel 1997: 138).

Olenemata sellest, kas värvus on kasutusel sümbolina või mitte, kirjeldab ta siiski alati ka objekti ennast. Muistendites ja muinasjuttudes tähendab must mees eranditult kuradit, ent samas ei tähista must üksnes selle tegelase deemonlikkust, vaid kirjeldab mingil moel kindlasti ka tema välimust - must võib olla nii mehe nahavärv, juuksed kui ka lihtsalt riietus (vt Valk 1998: 50-51). Regilaulus seevastu võib must mehe kirjelduses osutada tema töökusele, mida markeeritakse laulus jällegi välimuse kaudu (mees ei karda ennast tööga määrida) ${ }^{1}$ (vt Sarapik 1994: 41). See omakorda haakub Bengt Holbeki lähenemisega, kus väliste tunnuste ja atribuutide kaudu antakse edasi muinasjututegelaste sisemist olemust ja üldisi väärtushinnanguid. Kuigi Holbek värvusele eraldi tähelepanu ei pööra, osutab ta siiski selle sümboliväärtusele (kangelase väärtust markeerib näiteks kuldne juus) (1987: 442).

Alljärgnevalt vaatlen lähemalt värvuste esinemist eesti imemuinasjuttudes, keskendudes peamiselt neljale suurema sümboliväärtusega värvusele (must, valge, punane ja hall). Musta, valge ja punase tähendusvälju eesti kultuuris on avanud näiteks Virve Sarapik (1994, 1997, 1998) ja Tiiu Jaago (vt Roll 1985; Jaago 1997; Jaago 2016), kelle tähelepanekutele toetun ka käesolevas uurimuses. Muinasjutus kannavad värvifunktsiooni samuti metallid (vask, hõbe, kuld), peale põhivärvuste vaatan lähemalt ka nende esinemist.

Minu eesmärk on mõtestada värvuste tähenduslikkust muinasjutus kui poeetilises tekstis. Uurin, milliste tegelaste kirjeldustes üks või teine värvus esineb ning milliseid tähendusi neile mingi kindla tegelasega seoses omistatakse. Muinasjutud, millele käesolevas töös toetun, on kirja pandud 19. sajandi lõpust 20. sajandi keskpaigani, üksikuid tekste pärineb ka hilisemast ajast. Kõik põhivärvinimetused, mida tänapäeval tunneme, olid rahvaluulekogu formeerumise ajal eesti keeles juba kasutusel (vt Sutrop 2011: 397-420), seega võib eeldada, et kõiki neid esineb ka arhiivimaterjalis. Lähtun oma ülevaates 
eesti imemuinasjuttudest (ATU 300-749), mille digitaalne tekstikorpus on praegu kõige täielikum (korpus hõlmab ligi 12000 varianti, millest pooled on imemuinasjutud).

\section{Must ja valge}

Teiste värvustega võrreldes ümbritseb musta ja valget võrdlemisi lai tähenduste väli, mis hõlmab endas selliseid vastandpaare nagu hele-tume, valgus-pimedus, öö-päev, hea-halb, negatiivne-positiivne, räpane-puhas jne. Sellised binaarsed opositsioonid on üks maailma tajumise mudelitest (Dundes 2002: 150; Sarapik 1994: 37). Sageli pole need vastandid aga omavahel võrdsed, vaid seotud hierarhiliselt, mille aluseks on hinnangulised kategooriad (hea-halb, õige-vale, positiivne-negatiivne jms) (Jorgensen 2013a: 49). ${ }^{2}$

Regilaulude puhul toob Tiiu Jaago välja, et värvidele tuginevad parallelismipaarid "tähendavad koos olles midagi muud kui üksikult esinedes" (Jaago 1997: 61). Seega on oluline vaadata värvusi mitte üksnes iseseisvalt, vaid pöörata tähelepanu ka nende omavahelistele suhetele. Muinasjuttude puhul võib öelda, et musta ja valge tähendus jääb üldjuhul samaks, olenemata sellest, kas nad esinevad jutus eraldi või koos. Must tähistab enamasti halba ja ohtlikku ning on sageli seotud deemonlike jõududega.

Muinasjutus "Nõia õpilane" (ATU 325) saadab mees oma poja musta mehe juurde õppima ${ }^{3}$ :

Tie pääl puttu tälle must mies vasta, ja küsse: "Noh, mies, kohes sa ta tsuraga läät?"

“Lä̈̈ tõist kooli viimä,” kostõ mies.

Must mies kostõ: "Las ma koolita su poja targas mehes. Anna timä mu kätte kolmõs aastakas."

H II 70, 395/402 (31) < Setomaa, Misso v, Mokra k - Jaan Sandra < Mokra Marge [Mark] (1904)

Seos rahvausundiga on siin väga tugev: must mees või must loom on üks tuntumaid kuradi ilmumiskujudest mitte üksnes Eestis, vaid laiemalt Euroopa rahvausundis. Must värvus kajastub ka mitmes kuradi peitenimes: vanamust, must, must Ants, vana piginäpp (Valk 1998: 48-49).

Rahvaluulekoguja Martin Kraut on oma variandis muinasjutust "Puusärgi valvur" (ATU 307) kirjeldanud väga ilmekalt seda, milline näeb välja nõiutud kuningatütar:

Kui juba ööse saanud, hakanud surnukirst nagisema ja pagisema, kaan hakanud ikki kerkima ja kerkima, kuni viimaks maha kukkunud mis 
laginal ja surnu kirstust välja tulnud. Ta hakanud mööda kirikut käima, pool olnud tal musta, pool valget, pool inimese, pool kuradi nägu, ise turtsunud ikki: "Pühh, pühh, ristiinimese hais, pühh, pühh, ristiinimese hais," ja otsinud ristiinimest taga.

H II 26, 813/8 (9) < Suure-Jaani khk, Vastemõisa - Martin Kraut (1890) (vt EMj I: 1 2009: 108-109)

Tähelepanu väärib siin see, kuidas värvuste kaudu antakse edasi ühe tegelase olemuse muutumise protsessi - tema inimlikku poolt tähistab valge, mis annab märku, et nõidus pole kuningatütart veel täielikult haaranud, samas on pool temast juba "mustade jõudude" meelevallas.

Ka rahvausundis on musta ja tõmmut nahavärvi peetud pahaendeliseks. Teateid selle kohta, et eurooplased on kaldunud demoniseerima lõunapoolseid tumedanahalisi rahvaid, võib leida ristiusu algusaegadest (Valk 1998: 50-51). Eestis võis selline suhtumine üle kanduda mustlastele.

Mehe tütär oll illos, a naase tütär kui tsigandikõnõ musta pääga kui vanahalv.

S 84120/8 (49) < Setomaa, Vilo v, Saptja k - Anna Tammeorg < Grigori Loomik (1934), ATU 403C

Ka atribuudid, mida kurat või deemonlikud olendid kasutavad, võivad olla musta värvi.

Ühäl üäsä oli Mart pajas ja ühäkõrraga kuuli kolina. Vahib, et suur must tõld, neli musta suurt hobust ies, sõisab paja ies. Seesama vanames tuli tôllast vällä ja läks Mardi juure paja. Vanames ütäl, et kulla poiss, et nü̈d on 7 aastat täis ja nü̈̈d piad minuga kaasa tulema.

ERA II 268, 218/28 (8) < Jõhvi khk, Kohtla v, Kohtla k, Metsa t - Endel Mets $<$ Salme Mets, snd 1894 (1939), ATU $330+363+810$

Muinasjuttudes on peale kuradi teisigi üleloomulikke tegelasi, keda musta värvuse kaudu iseloomustatakse. Näiteks osutub must värv oluliseks tõrjemaagias, ning selles kontekstis omandab must positiivse tähenduse.

Muinasjutus "Kuningatütar klaasmäel" (ATU 530) peavad pojad valvama isa haual:

Aga enne korjas ta kaalkoti sisse pisukesi uba, kive ja pähklid ja võttis oma musta kuke ja musta kassi ka ligi.[---]

Korraga hakkas kukk laulma ja kass näugma ja saksad kadusid seepeale kõik ära.

EKmS $4^{\circ}$ 5, 455/9 (428) < Helme khk - Aleksander Wahlberg < Jaan Hiop (1873/4), ATU 530 + 1061 (vt EMj I: 2 2014: 144-147) 
Rahvausundis on musta värvi kukk ja kass maagilise funktsiooniga - nende abil peletatakse kuradit. Just värvuse kaudu väljendatakse kuke suhet kuradisse sellise ütlusega: must on murdja, kiriv on kiskja, punane on poolvend (lõunaeesti k: verrev veli, valge vader). Ebaselgeks jääb siiski, mida tähistavad need värvused hea ja halva teljel. Ühelt poolt toetub see ütlus alliteratsioonile, teisalt on siin osutatud mustale kui kõige tugevama maagilise tähendusega värvusele (vt Hiiemäe 1999: 19-20).

Sarnaselt mustale osutab ka valge looma üleloomulikule olemusele, kuid erinevalt mustast on valget värvi loom enamasti kangelase abiliseks (vt ka Agirel 2009: 93, 95). Muinasjutus "Härg abiliseks" (Ee 511A) hoiatab valge härg poissi võõrasema eest, kes tahab teda tappa, ning aitab poisil põgeneda (EMj I:2 2014: 633-634). ${ }^{4}$ Jutus "Tark hobune" (ATU 531) käib valge mära mehe viljapõllul söömas, kangelane püüab ta kinni ning saab tasuks vabastamise eest endale imelise hobuse. ${ }^{5}$

Musta seos halva ning deemonliku maailmaga on muinasjuttudes väga tugev ning toetub suures osas usundilisele maailmakäsitlusele. Ka valge on seotud üleloomuliku maailmaga, kuid pigem positiivses tähenduses.

Kristlikus värvisümboolikas seostub valge puhtuse ja süütusega. Valges rõivas kujutatakse näiteks ingleid, aga ka Neitsi Maarjat ja Kristust. Ello Kirss on pannud kirja järgmise uskumuse:

Seto rahvas om Pühä-Maarja rahvas. Pühä-Maarja oll ka käünü valgõ särgiga. Ku na suurõ' sbıja' olli, sbıss üts mẹes oll saanu unõh küssü, et kas no vast jo pia ar' ots tetäs soolõ ilmalõ. Tälle oll ült, et nii kavva, ku vẹ̣l valgõ rüvvega rahvast om, tulõ-i otsa.

ERA II 194, 334/5 (2) < Setomaa, Meremäe v, Palo k - Ello Kirss < Od'o [Jevdokia] Palomaa, snd u 1877 (1938)

Rahvajuttudes kannavad valgeid riideid ${ }^{6}$ või jalanõusid pühakud:

Mikul oll' ülnü tọod ka', et kiä ẹne minnu käu ar' rüänurmõ ikkõh, tood ma ẹämb praavida-i. Enne ikku-i midägi, ku ma ọmmi valgite saabastõga ar’ käü üle nurmõ. Mikul om poissa puusli, nurmõ kaeja.

ERA II 194, 413 (20) < Setomaa, Vilo v, Vilo k < Petseri v, Unkavitsa k Ello Kirss < Ann Pääsläne, snd 1863 (1938)

Musta ja valge abil ei markeerita muidugi üksnes muinasjututegelaste üleloomulikkust. Samavõrd oluline roll on värvusel ka tegelaste ilu ja inetuse rõhutamisel. Muinasjutus "Must ja valge pruut" (Ee 403B) võtab mees endale uue naise. Mehe ja naise tütart on omavahel võrreldud selliselt:

[---] võera ema tütar oli inetu ja must, aga võeras tütar oli ilus kui uaõis. EKmS $4^{\circ}$ 5, 812/8 (14) < Pilistvere khk - T. Kiimann (1888) 
Üleloomulikkuse rõhutamisele lisandub siin esteetiline aspekt. Kuid folkloorses tekstis ei ole ilu üksnes esteetiline kategooria, sellele lisandub mitmeid teisigi väärtusi, nagu noorus, tervis, elujõulisus, fertiilsus. Soorolle käsitlevad uurimused on leidnud, et ilu (ka inetus) on muinasjutus soospetsiifiline ning tõuseb esile peamiselt seoses naistegelastega (Baker-Sperry \& Grauerholz 2003; vt ka Toomeos-Orglaan 2013: 58).

Musta ja valge opositsioonilisus tulebki muinasjuttudes kõige paremini välja naistegelaste kirjeldustes. Jorgenseni (2013a: 64; vt ka 2013b: 191) uurimuse kohaselt kirjeldatakse muinasjuttudes naise keha ja välimust mehe omast sagedamini. Temagi materjalis on populaarsemateks värvisõnadeks must ja valge, kolmandana nimetab ta valgega kattuvat kahvatut nahatooni (pale). Kahvatu seostub rahvajuttudes väga konkreetselt vaid nahaga. Must värvus iseloomustab Jorgenseni sõnul rohkem meest, samuti pruun ja kuldne. Punane ja kollane ilmnevad nii mehe kui ka naise kirjeldustes. Üksnes naise puhul leidsid aga kasutamist väljendid blackened, white and beautiful, whitened, alabaster, dark, spotted. (Jorgensen 2013a: 64) ${ }^{7}$

Kehalisus, millele Jorgensen oma uurimuses keskendub, on nähtav ka eesti muinasjuttudes. Nii sümboliseerib valge jume, mis on preemiaks hea käitumise eest, naiskangelase positiivseid omadusi, must rõhutab jällegi vastandtegelase pahelisust.

Muinasjutus "Vaeslaps ja peretütar" (ATU 480) kohtab vaeslaps lehma, kes palub, et tüdruk teda lüpsaks ja ütleb:

“Joo sie piim ära, ja sa pead niisama valgese saama ja jääma kui sie piim om, sest sie om sinu sõnakuulmise palk.” Ja tüdarlaps tegi seda kudas lehm teda käsk, ja läits valgemase viel kui piim. Nüid pani ta nüsku jälle lehma sarve otsa ja lippas minema.

Selles jutuvariandis läheb ka võõrasema tütar sama teed, et kõiki neid hüvesid saada, kuid jätab lehma lüpsmata. Karistuseks ütleb lehm talle:

“Jäägu sa viel mustemase kui maa; et sa minu äda es kuule ega mu soovi es täida." Ja nõnda ka oli, ta läits silma nätten mustasse kui maa.

H III 14, 77/98 (3) < Tarvastu khk, Tarvastu v, Tüma t - Jaan Viira (1891), ATU $480+$ Ee 403B

Dorothy Hurley juhib tähelepanu, et valge nahavärvi eelistamine positiivse naiskangelase kujutamisel on osutunud probleemiks mustanahaliste laste identiteedi kujunemisel. Kujutluspilti ideaalsest naisest on aidanud luua muinasjuturaamatute illustratsioonid ning Disney muinasjutufilmid, mis lähtuvad suures osas euroopalikust (“valgest”) kultuuriruumist. (Hurley 2005) 
Vastandvärvidele toetub ka tasu ja karistus muinasjutus "Vaeslaps ja peretütar" (ATU 480). Nimelt saab vaeslaps valida musta ja valge karbi vahel. Valges karbis on kuld ja hõbe, mustas aga tuli ja tõrv.

Peräst vihtmist ütel vanamiis: "Kae, saina veeren om kats karpi, üts must, tõne valge; võta valge omale, selle èest, et sa minnu ilusti vihtsed. Kutsu pühäba sugujagu kokku ja võta töo karb kõigide näten valla!” Ütel ja katte. Vaene lats tei nindade. Karpi valla teten tulli säält kikkesugust kallist asja võtmise pääle vällä, mida mèel egänes sóovse: kulda, hõpet, sametit, siidi.

H II 43, 99/100 (1) < Helme khk, Koorküla - K. Ruut (1892)

Peale hea-halva ning väärtuslik-mitteväärtuslik tähenduste võib siin näha otsest seost ja analoogiat - tõrv ongi musta värvi ning hõbedat on peetud valge läikeliseks variandiks (vt Sarapik 1994: 38).

Kirjeldatule lisaks võivad must ja valge olla kasutusel ka teistel põhjustel. Nii nagu must võib tähendada räpasust, võib valge seostuda puhtusega:

Kui vaenelats sanna läts, olliva ka vanahalva vihtleman, nink es lase tedä sanna mant väele tulla, enge vanapagan esi aste ette ja ütel: "Tule ärä mu pojale naises!”

Ent tütarlats ütel: "Kost ma või õige minnä, mul ei ole säljan valget hametki."

Vanapagan ütel pojale: “Joose poig, joroda poig, too tälle valge hame, joose poig, naine saa hü̈̈!’ Vanapagana poig joosk ja jorot, ja sedämaid olli valge hame sääl, mida vaenelats sälgä pidi pandma.

E 17609/10 (4) < Vastseliina khk, Vastseliina v - Jaan Sandra < Mai Sandra (1895)

Motiivis, kus võõrasema annab vaeslapsele ülesandeks mustad lõngad valgeks ja valged lõngad mustaks pesta (Ee 403B), tähistab selline vastandile ülesehitatud kujund ennekõike rasket ülesannet, mida on võimatu täita.

Võerasema pannud võera tütrele nü̈̈d jälle õhukesed ja lagunud riidi hilbud selga, annud temale mustad lõngad kätte ja käskinud jões lumi valgeks peseda.

E 2927/32 (47) < Helme khk - Jaan Karu (1893)

Samasse kategooriasse võib paigutada ütluse 'räägib musta valgeks'.

Jututüübi "Naine libahundiks" (ATU 409) variandis on valenaise jaoks kaevatud augu peale asetatud valge lina. 
Jällegi õppetatud meest, kaeva toa ukse alla suur sügav hauk, keeda se hauk kuuma sõnnikud täis; kütke ahi ära ja minge vihtlema, aga katke haugu peale suur valge puhas lina, on ta ennast pesnud, läheb kambri riidesse panema, küsib ta, miks pärast on se lina siia maha pandud? H II 11, 870/6 (2) < Väike-Maarja khk, Kiltsi v - Jakob Palm (1890)

Sellisel juhul ei tähenda valge ilmselt muud kui lina tavapärast värvust.

\section{Punane}

Musta ja valge kõrval on üks olulisematest värvustest punane, mis on kontrastiks eelnimetatud värvustele ning hakkab ka üldises looduskeskkonnas hästi silma. Kahtlemata on oluline punase assotsiatsioon verega (Sarapik 1998: 22).

Kultuuris laiemalt on punase värvi tähtsus märkimisväärselt suur. Varasemal ajal oli kindlate tavadega näiteks reglementeeritud see, kellel ja mis ajal on sobilik punast värvi riideid kanda. Punasel rõivastusel on üldiselt olnud positiivne tähendus, seda on peetud ilusaks, kuid oluline on ka selle värvuse maagiline tähendus. Punane riietus või kaunistuselemendid on olulised sünni- ja pulmakombestikus, leinariietuses seevastu punast välditakse (Sarapik 1998: 26-27; Jaago 1997: 71-72). Siinkohal tasub meenutada Kihnu naiste rõivaste värvireegleid, kus punane kuulub tavaliselt just noorte fertiilses eas naisterahvaste riietumistavandisse (vt Kalits 1997: 27-29).

Muinasjuttudes leiab punast nii positiivses kui ka negatiivses seoses. Nagu must ja valge, on ka punane sageli seotud üleloomuliku maailmaga. Ühes jututüübi "Naistetapja ja kolm õde" (ATU 311) variandis ilmub kurat tüdrukute juurde punast värvi jänesena.

Elli paabakõnõ. Olli kolm tütärd. Läts’ kõgõ vanõb tütär riida mano puid tuuma. Sääl verrev jänesekene. Nakas' tuud jänest kinni võtma. Jänsekene pakku. Läts' paja ala. Vanasitt oll’. Kuts naases.

ERA II 301, 277/80 (123) < Setomaa - Liis Pedajas < Jevdokia Lumejärv (1942), ATU 311 (vt EMj I: 1 2009: 113-115)

Kuradi zoomorfsetest ilmumiskujudest on jänes eesti rahvausus üks tüüpilisemaid (Valk 1998: 104), siinkohal väljendab punane kui jänesele mitteomane värvus veelgi selgemalt tema deemonlikkust. Valk nimetab sellist ebaharilike tunnuste esinemist "välimuse anomaaliaks" (Valk 1998: 105). Folkloorses tekstis markeeritakse selliselt tavapärasest erinevaid tegelasi ja nähtusi.

Hoopis teise tähenduse omandab punane aga noore naise kirjelduses, kus see haakub ennekõike tähendusega ilus (Sarapik 1997: 28-29). 
Vaenelaps oli peres teenimas. Ta pidi alati rasket tööd tegema, kuna peretütart hõlbutati. Kuid sellegipärast oli vaenelaps priske ja punane ja ilus nagu puuõun, aga peretütar näotu ja must.

EÜS VIII 2453/7 (6) < Kuusalu khk - Karl Viljak, Gustav Vilberg < Mai Kravtsov (1911), ATU 403C + 409

Väljend priske ja punane on regilaulust tuntud kinnisepiteet.

Võtsin mullu naese noore, tunamullu teisepoole.

Küll oli priske ja punane, küll oli värske ja varane, küll oli terve ja terane.

H III 2, 639/40 (33) < Haljala khk, Sagadi v - J. Umblia (1889) (Eesti regilaulude andmebaas http://www.folklore.ee/regilaul/andmebaas/)

Punase seos tüdruku või noore naisega on märkimisväärselt suur nii muinasjutus kui ka regilaulus (vt Jaago 2016). See, milliseid väärtusi, omadusi ja ka väliseid tunnuseid noore abiellumisealise naise juures on oluliseks peetud, tuleb esile näiteks noort mõrsjat kiitvatest pulmalauludest. Ilu, noorust ja headust rõhutavad valge ja punane, inetust ja vanadust seevastu must ja sinine (vt Roll 1985: 38-39).

Kui türgi ja aseri muinasjuttudes annab punane märku kangelase küpsusest, olenemata tema soost (Agirel 2009: 95), siis eesti traditsioonis kasutatakse punast ennekõike naiskangelasega seoses.

Muinasjutus “Üheksa velje sõsar” (Ee 451A) antakse punase lõngaga märku tüdruku sündimisest.

Ühel naesel oli seitse poega. Kui pojad meheks kasvasid, siis tulid nad ema juurde ja küsisid: "Ema, kas meil õde ka on?” Ema vastas: "Ei ole!” Pojad lubasid ära minna ja ütlesid: "Nüüd lähame meie ära. Kui sull poeg sünnib, siis pane kirvesilm katuksele, aga kui sull tütar sünnib, siis pane punane lõnga-rist katuksele, kui meie kirvest katuksel näeme, siis ei tule meie mitte tagasi, aga kui lõnga-rist katuksel on, siis tuleme meie tagasi, sest et meie siis tääme, et sull tütar on.”

E 18942/4 (3) < Viljandi - Jaan Adeleid (1895), Ee 451A + ATU 511

Punasel lõngal on eesti rahvauskumustes ja kommetes üleüldiselt oluline koht. Seda on kasutatud nii pulma- kui ka sünnikombestikus (Sarapik 1998: 25-26) ja rahvameditsiinis (Kõivupuu 2008: 371; Kõivupuu 1999). Tüdruku sündimise tähisena katusele kinnitatud lõnga värvust võib seega pidada traditsioonile omaseks. 
Punase positiivset tähendust aitab veelgi rõhutada vastandamine mustaga. Sellisel juhul markeerivad punane ja must ilu ja inetust, kus mustale võib lisanduda (kuid ei pruugi) viide tegelase deemonlikkusele.

Lisaks seni kirjeldatud värvipaaridele võivad must, valge ja punane esineda muinasjutus ka kolmikuna. Portugali muinasjutu-uurija Francisco Vaz da Silva keskendub just sellele värvikombinatsioonile "Lumivalgekese" (ATU 709) muinasjutu näitel. Kõige üldisemalt tähistab valge Vaz da Silva sõnul puhtust, süütust ning mingisugust vahepealset aega enne kui tüdrukust saab naine; punane viitab verele ja fertiilsusele; must kujutab nõidust ning surma (Vaz da Silva 2007: 243-247).

"Lumivalgekese" eesti variandid toetuvad üldjuhul vendade Grimmide versioonile (vt Sutrop 2016).

Üks kord istus üks kuninga proua akna all, ja vatas kui lumi sadas, siis juhtus et tema kogemata nõelaga sõrme torgas, ja sealt tuli verd valja, Tema jäi motetese, ja vatas sõrme peale kui sealt verd valja tilgus. Siis ütles tema ise enneses, oleks mull üks tütar olevad, kes nii valge ihu karvaga kui lumi, ja nii punased paled kui veri, ja mustad juksed kui süssi. Aasta pärast laks ka ema soovimene täide, tema sünidas tütar lapse ilmale, kes oli ilus kui lõuna poolt õun.

E 20874/88 < Märjamaa khk, Mõisamaa v - Jaan Veedam (1895), ATU 709

Nii siin kui teisteski jututüübi variantides on esil Lumivalgekese välimus, tema keha (valge ihu, punased palged, mustad juuksed) väljendab omaaegset iluideaali (Vaz da Silva 2007: 242).

Siinkohal juhin tähelepanu veel ühele jututüübile, kus värvikolmiku (mustvalge-punane) kaudu iseloomustatakse naiskangelase olukorda või seisundit.

Seto muinasjutu "Söepuder" (Ee 327H*) algusepisood keerleb selle ümber, et tüdruku keha on muutunud mustaks ning ta viiakse ojja ligunema.

Oll’ imä ja esä ja tütär, poig. Imä esägä lätsi kostõlõ, veli sõsarõga jäi kodo. Sõsar ütel velele: "Naakõ errä pidämä!”

"Midäs mii pia?"

"Naakõ hütsi surbma!"

Surbi, surbi ja peräkõrd lätsi väega mustast ja sõsar ütel velele: "Võih, sa olt' mustakõnõ," ja veli ütel vasta: "Sa eiis ol't pall'o mustõmb ku ma!" Sõsar ütel: “Läki, vii minnu ojja ar' likko.” Ja veli läts ka.

S 78230/2 (3) < Setumaa, Vilo v, Veskova k - Mihail Peramets < Vassa Toomik, Lübo [Ljubov] Juurik (1934), Ee 327H*

Punane ja valge värv lisanduvad, kui vend läheb oja äärde küsima: 
Sõsari, sõsari,

kas olt puhas punanõ,

merevatu valgõ.

S 78230/2 (3) < Setumaa, Vilo v, Veskova k - Mihail Peramets < Vassa Toomik, Lübo [Ljubov] Juurik (1934), Ee 327H*

Punase ja valge esinemine paralleelvärssides on omane regilaulule, sellise poeetilise kujundi abil korratakse ja rõhutatakse olulist mõtet. Paralleelvärsis, üksteist täiendavana, kannavad eri värvused sama tähendust (vt Roll 1985: 41-42). Õe muutumine mustaks pärast söe söömist toetub ühelt poolt muidugi analoogiale. Sümboolses tähenduses võib aga õe muutumist tõlgendada tema demoniseerumise või isegi suremisega. Sellist kujutlust toetab mõneti ka loo edasine kulg, nimelt käib vanahalb omakorda õde küsitlemas ning meelitab ta endaga kaasa. Punane ja valge saavad selle loo kontekstis elu ning tervise tähenduse just mustale vastandudes.

Sarnaselt valgele on muinasjuttudes punase vastandiks sageli must värvus. Muinasjutus "Vaeslaps ja peretütar" (ATU 480) saavad nii naiskangelane kui ka tema vastane vastavalt oma käitumisele tasuks karbid. Enamasti on need karbid ka mingisugust värvi. Ühte ja kindlat värvipaari siin küll välja tuua ei saa. Ka assotsiatsioonid, mida värvipaarid loovad, on erinevad. Punase ja musta karbi puhul on väärisasjad just punases karbis ning mustast paiskub välja tuli ja tõrv. Ühelt poolt rõhutavad karpide värvused, samuti saadud tasu, vastandtegelaste olemust (hea-halb). Punane assotsieerub positiivse ilusa ja noore naiskangelasega, must osutab aga vastase deemonlikkusele. Teisalt osutab tõrv mustas karbis analoogia seosele.

Negatiivse või halva tähenduse omandab punane siis, kui vastandus luuakse valge värvuse abil.

Mitmes jututüübi "Vaeslaps ja peretütar" variandis tuleb tüdrukutel valida valge ja punase karbi vahel. ${ }^{8}$ Siingi võib põhiseose loomisel olla määravaks analoogia - valges kastis olev hõbe seostub valge läikelise vormiga ning punane tulega.

Erandlikuks võib pidada Mai Kravtsovi jutuvarianti Kuusalu kihelkonnast, kus tüdrukutel tuleb valida punase ja sinise karbi vahel:

Kivi ääres olnud kaks kasti, üks sinine, teine punane. Vanamees käskis ühe kasti omale selle ette vaevapalgaks valida, et ta teda muda august välja kiskus. Vaenelaps mõelnud: "Ma olen vaenelaps, mis ma punasega teen, võtan parem sinise,” ja võttiski sinise. [---] Kastis oli kõiksugu ilusaid kuld ja hõbe ehteasju, mis kõik vaeselapse omaks saivad. [---] Viimaks jõuab ka tema [peretütar] kivi juurde, mille ääres jälle kaks kasti seisavad, üks punane, teine sinine. Tema mõtleb: "Ei mina, peretütar, sinist taha, ma 
võtan ikka punase." Viimaks sai lühi kätte ja hakkab kastiga koju minema. Kodu viidi kast aita ja tehti suure igatsusega lahti. Kastist tuli aga suur tuleleek välja ja põletas kõik ära-peretütre ja maja ja varanduse. Kes upsakas on, selle käsi käib ikka pahemini kui sellel, kes alandlik on. EÜS VIII 2457/9 (7) < Kuusalu khk - Gustav Vilberg < Mai Kravtsov (1911/2), ATU 480

Eelduspärane on, et vaeslaps valib siingi punase karbi. Punasest kui ilusamast ja uhkemast loobumine rõhutab aga naiskangelase vooruslikkust, mida kinnitab ka jutu lõppu lisatud moraal.

\section{Hall}

Kõige tuntum muinasjututegelane, keda selle värvuse abil kirjeldatakse, on kangelase abiline ja nõuandja hall vanamees. Halli vanamehe tegelaskuju on tuntud ka teistel rahvastel (Apo 1986: 263).

Tavapäraselt kohtab kangelane halli vanameest siis, kui ta lahkub kodust mingisugust ülesannet täitma. Hall vanamees annab kangelasele nõu, kuidas eelseisva ülesandega hakkama saada või kingib talle imelise abivahendi.

Sageli ilmub hall vanamees kangelase juurde sandi või kerjusena. Halli tähendust otsides võime järeldada, et neil juhtudel markeerib hall kangelase abilise riietust. Kuid hallil näib olevat teisigi tähendusvarjundeid. Imemuinasjuttudest tuntud hallil vanamehel on ühisjooni legendilistest muinasjuttudest tuntud jumala, Kristuse või pühakute tegelaskujuga, kes tegutsevad ja liiguvad jutumaailmas sageli halli vanamehe või kerjuse kujul (vt ka Apo 1986: 263).

Erinevalt teistest värvustest jääb hall üldjuhul looduses märkamatuks. Kui valge, punane ja must rõhutavad mingi objekti või tegelase erilisust, siis hall näib toimivat vastupidiselt, püüdes tegelase erakordsust varjata. Nii võib halli pidada suurepäraseks maskeeringuks, mis aitab peita nii jututegelase ebatavalist tarkust kui üleloomulikke võimeid. Tarkuse aspekti toetab ka tavaelus levinud arvamus, et hallipäised inimesed on (elu)targad.

Halli vanamehe kujul võib kangelast abistada nii jumal ${ }^{9}$ kui kurat. Sarnaselt muistenditele ei ilmne kuradi tõeline olemus kohe, vaid alles loo käigus või päris lõpus. Jututüübis "Kolme rännumehe kaup kuradiga" (ATU 360) kohtuvad mehed halli vanamehega, kes võtab nad enda juurde tööle. Alles lõpus selgub, et abistajaks on kurat.

Siis sõitnud üks tôld sinna ja ütelnud juba eemalt: "Pidage!” ja üks uhke härra astunud tõllast välja. Ei ole neid lasknud üles tõmmada ja temal 
olnud teine inimese jalg ja teine hobuse jalg. Siis ütelnud ta kohtumeestele, et need pole tapjad, et kõrtsimees on vallavanema ära tapnud.

H II 28, 874/880 (4) < Maarja-Magdaleena khk, Kaiavere v - Aleksander Vuks (1889), ATU 360 (vt EMj I:1 2009: 278-279)

Kuna hall seostub muinasjutus enamasti positiivse tegelasega, siis võib kuradi sellist ilmumiskuju pidada teataval määral maskeeringuks. Erinevalt positiivsest abilisest on kurat enamasti omakasupüüdlik ning nõuab abistamise eest midagi vastutasuks (nt kangelase hinge; esmasündinud last vms). Hall värvus on iseloomulik ka mitmesuguste uskumusolendite kirjeldustes, haigusvaimudest võivad halli vanamehe kujul liikuda nii halltõbi kui katk (Paal 2014: 85-86; vt näiteid samas 176-177; Hiiemäe 1997: 51-52).

Loomade puhul esineb halli värvust muinasjuttudes kõige sagedamini hundi kirjelduses. Muinasjutus "Kuldne lind" (ATU 550) abistab kangelast hall hunt. Ühelt poolt on muidugi tegemist hundile omase värvusega. Teisalt on halli kinnistumisele aidanud kaasa ka nimisõna ja omadussõna koosesinemisel tekkiv alliteratsioon (hall/hahk hunt).

Imemuinasjuttudes on hunt sageli üleloomuliku abilise rollis. Sarnaselt halli vanamehe tegelaskujule ei osuta hall värvus hundi puhul otseselt tema ebatavalisusele, see selgub alles loo tegevustiku käigus. Ent märksa selgemalt tuleb hundi erilisus välja seto jutuvariantides, kus ta võib olla valget või sinist värvi (sinine susi). Kui halli puhul tekibki kahtlus, siis valge ja sinine oma erakordsuses osutavad selgelt hundi üleloomulikkusele.

\section{Teised värvused}

Regilaulu poeetikas on musta, valge ja punase kõrval olulise tähendusväljaga ka sinine värvus. Sinise ja punase koosesinemine pulmalauludes osutab sünni ja surma kõrval inimese elus veel ühele olulisele piirsituatsioonile, milleks on abiellumine. Piirsituatsioonis markeerivad punane ja sinine elu ja surma, siin- ja sealpoolsust (Jaago 1997: 60-61). Sellest lähtuvalt sümboliseerib sinine (sinirätt, sinisiibo lin’kenõ) surma ka jututüübis "Vaeslaps käoks" (ATU 720). ${ }^{10}$

\section{Käiokeñ̃}

Uma imä kuuli ar. Esä võtt teesõ naase. Sai latsilõ imäk. Imäk tapp nooreba tütre ar, and esäle liha süvvä, velele vere juvva. Nu sei, pill' luu' pingi ala. Sõsar luu' kokko koräs, mähe siniräti sisse, veie tammõ osõkeisdõ. Luist sai sääl käokenõ - sinisiibo lin’kenõ. Linnas esä aia pääle, nakas halõhõhe kuukma:

"Kuu ku, kuu ku, 
umä ime arä kuuli, ämmäk imä arä tapi, kuu ku, kuu ku!

Esä seie mino liha, kuu ku, kuu ku!

Vellö seie mino vere, kuu ku, kuu ku!

Sõsar luu' kokko koräs, kuu ku, kuu ku!

Mähke siniräti sisse, kuu ku, kuu kuu!

Veie tammõ osõkeisdõ, kuu ku, kuu ku, säält ma saie käokenõ, kuu ku, kuu ku, sinisiibo tsirgukenõ, kuu ku, kuu ku!

Imäk ütles tütrele, et mine lü̈̈ tälle. Läts sõsar lüüma - hiit sõsarõlõ suurõ sõlõ ni katte esski ar. Tull' teenõ hummok, jall linnas käokenõ esä aia pääle ja kuuk noid samtit sõnno. Imäk sai viil vihasabast, saat poja käko pessmä. Läts veli vällä - hiit velele saapa'. Hinnäst nigu olõki-õs. Tull' kolmas hummok - imäk saat mehe käko virotama. Läts esä vällätoolõ hiit kartusõ. Tull' neläs hummok - kägo jall kuuksõ esä aia pääl. Kai imäk, et saa-õs teisist midägi - läts ess käokeist virotama. Käokenõ hiit tälle ka, õnne hiit kiviga. Sai kivi pääle, tappu ämmäk imä ar.

S 206/8 (17) < Setomaa, Meremäe v, Helbi k < Serga k - Ekaterina Põllula < Anna Kõiv, 40 a (1926), ATU 720

Muinasjutule tüüpilisem on aga sinise esinemine kuradi kirjelduses. Sinised võivad olla kuradi riided, tegelaskuju deemonlikkusele viitab ka sinine habe Charles Perrault' tuntud muinasjutus ("Sinihabe”, ATU 312). Mitmes jutus tõmbab kurat ennast loo lõpus lõhki, nii et temast jääb järele ainult sinine suits või sinine veelomp. Mustjassinine võib olla ka kuradi veri:

Vahva nuormies ragi nimä kõik uma kullatsõ, kotost üteh võetu mõõgaga purus. Terve kolm üöd ja päivä tekk mehekene ilma vahetpidämätä tüöd, kooni vannuhalvu sinine must veri jõe viisi tühja pae saart pite edesi voolas.

H II 72, 320/37 < Setomaa, Meremäe v, Sulbi k - Jaan Sandra < Sulbi Joorka [Jegor] (1905), ATU 650A 
Nagu teistegi värvuste puhul, tähistab sinine looma kirjelduses tema ebatavalisust ja üleloomulikkust, sinist värvi loom tegutseb enamasti kangelase abilisena (nt sinine susi jututüübis "Kuldne lind", ATU 55011).

Tiiu Jaago sõnul ei ole roheline, lilla ja pruun oma nooruse tõttu regilaulu keelde juurdunud (Jaago 1997: 56). Nooruse all on mõeldud nende värvisõnade hilist jõudmist eesti keelde (vt Sutrop 2011). See ärgitas omakorda järele vaatama, milline on nende värvuste esindatus muinasjuttudes. Selgus, et lillat ja oranži ei ole mainitud üheski eesti imemuinasjutus. Vähesel määral on siiski nimetatud pruuni, roosat ja kollast värvust.

Aga seal noormees laskis oma pruuni koera keti otsast lahti ja ütles: "Murra maha!" Aga ütles nii, et keegi ei kuulnud.

ERA II 63, 379/88 (4) < Tartu-Maarja khk, Kavastu v - Richard Viidebaum < Kaarel Jürjenson, snd 1868 (1933), ATU 300 (vt EMj I: 1 2009: 31-34)

Padjas oli aga kolm kleiti ja pruunid kingad. Üks kleit oli nagu taevatähed, teine kuu, kolmas päike.

EKRK I 29, 585/9 (24) < Tartu raj, Emajõe kolhoos < Koosa - Tiia Vitsur $<$ Anna Kõiv, 74 a (1960), ATU 480 + 510A

Pruunid koerad "Lohetapja" (ATU 300) muinasjutus ja kingad "Tuhkatriinu" (ATU 510A) loos mõjuvad neis näidetes pigem tavalise ja argisena ning mingisugust sümboolset tähendust siin ilmselt ei ole.

Roosa muutus põhivärvinimeks väidetavalt alles 20. sajandil (Sutrop 2011: 414), kuid küllap tunti seda juba 19. sajandi lõpukümnenditelgi. Muinasjutukorpuses esineb roosa värvus vaid paaris jutuvariandis. Neist vanim on 1893. aastal üles kirjutatud "Tuhkatriinu” (ATU 510A) variant:

Manni vottas nüüd pakki lahti ja sääl sees oli oige ilus roosa siidi kleit, roosad saapad ja roosa kübar. Nü̈̈d pani Manni ennast riide ja läks paali pääle. Paali pääl vahtisivad täda keik imestusega, sest täma oli keige ilusamb. Keige rohkemb aga vahtis täda kuninga poiga, eiga vottand toisist tütrikusist tegemistgi, vaid oli alati Manni juures.

H II 36, 687/692 (57) < Vaivara khk - Aado Kõrbe (1893), ATU 510A

Ilmselt võib nõustuda Eda Kalmre tähelepanekuga, et Kõrbe üleskirjutus toetub mõnele kirjanduslikule eeskujule (Kalmre 1989: 138). Kui roosat 19. sajandil tuntigi, siis küllap just kirjanduse kaudu.

Kirjanduslike muinasjutuversioonide mõju võib märgata teistegi värvuste puhul. Nii on Martin Sohbergi Jututoojate sarjas ilmunud jutu "Varastatud kuningatütar ja ära tõutatud poeg” (Sohberg 1876) toel suulisse jututraditsiooni kandunud motiiv, kus kangelane tohib igale küsimusele vastata üksnes "roheline", sellest kujuneb loos ka kangelase hüüdnimi. ${ }^{12}$ 
Rohelise värvuse kasutamine muinasjuttudes näibki olevat juhuslikumat laadi. Mitmesuguste looduspiltide kõrval (nt "kõrged rohelised kaldad"13, "suur roheline plats"14) on rohelist kasutatud küll ka sümboolsemates kujundites, kuid siis asendab ta (ka vastandudes punasele) tavaliselt sinist. Sinise asendajana võtab roheline üle kogu sinise tähendusvälja, mis usundilistes kujutelmades seostub ennekõike kuradi ja deemonlikkusega. Tegelase üleloomulikkusele viitab roheline ka ühes "Laibasööja" (ATU 363) jutuvariandis, kus tüdruk ütleb, et abiellub ainult mehega, kellel on roheline nina ${ }^{15}$ (tüübile omasem on kuldse ninaga mehe soovimine). Kuigi roheline on selle jututüübi kontekstis ebatraditsiooniline, tähistab see siingi sarnaselt kuldsele tüdruku ihalust millegi ebatavalise järele. Kuradiga seoses kannab roheline kahtlemata negatiivset väärtust, samas võib rohelisel punasele vastandudes olla ka positiivne tähendus (rohelises karbis on kuld, punases hävitav tuli). ${ }^{16}$

\section{Metallid}

Vask, hõbe ja kuld tähistavad muinasjutus ühtaegu nii materjali, värvust kui ka objekti väärtust (Lüthi 1982: 27; Agirel 2009: 99). Sageli moodustavad vask, hõbe ja kuld gradatsiooni, kus kuld on kõige väärtuslikum.

Jututüübis "Kuningatütar klaasmäel" (ATU 530) saab kangelane, kes valvab kolmel ööl isa haual, kingituseks vaskse, hõbedase ja kuldse hobuse. Ta püüab ratsutada nende hobustega klaasmäe otsa. Vaskse ja hõbedase hobusega ei õnnestu tal päris tippu jõuda, küll aga kuldse hobusega. Vask-, hõbe- ja kuldesemed, mis kangelane kingiks saab, on enamasti imelised. Tähelepanu väärib, et enamasti premeeritakse nende esemetega just meeskangelast. Kui naise väärtust antakse muinasjutus edasi tema välimuse kaudu (ilus-inetu), siis meeskangelase sisemisi väärtusi markeerivad imelised atribuudid, mis tal loo käigus õnnestub saada (nt imeline mõõk, imelised abilised jms). Seyfi Agirel toob türgi ja aseri rahvajuttude puhul välja, et nii kuld kui hõbe kangelase kirjeldustes (näiteks juuksed, ATU 314) viitab tema ilule (Agirel 2009: 99). Esteetilist hinnangut ei saa muidugi välistada, kuid just meeskangelase puhul näib ilu olevat siiski teisejärguline. Pigem tähistavad kuldsed atribuudid ja ka välimus kangelase varjatud väärtusi (Holbek 1987: 442, vt ka ToomeosOrglaan 2013: 57).

Kui kangelane saab ülesandeks tuua midagi kuldset, siis võib seda tõlgendada kui rasket ülesannet, mida on peaaegu võimatu täita. Jututüübis "Poiss varastab kuradi varandust" (ATU 328) saadavad vanemad vennad noorema põrgusse kuldemist, kuldhane, kuldhobust või kuldtoobrit tooma ${ }^{17}$. Muinasjutus "Tark hobune" (ATU 531) leiab kangelane teelt kuldsule, hiljem peab ta tooma kuldlinnu, kuldhobuse ja lõpuks ka kuningatütre. ${ }^{18}$ 
Just kuld mõne looma või linnu välimuse kirjelduses (nt kuldpart, kuldoinas, kuldhobune, kuldlind, kuldkala) annab kõige selgemalt märku tema imelisusest. Sama kehtib kuldesemete kohta.

Kulda näib armastavat ka kurat. Tema valduses võivad olla kuldsed esemed, mille järele kangelane peab minema, kuid kuldne võib olla ka kurat ise (kuldsed juuksed või habe jututüübis "Kolm karva vanakuradi peast", ATU 461). Jututüübi "Sinihabe" (ATU 312) eesti variantides muudab kurat end kuldmunaks ning meelitab nii tüdrukud endale järgnema (vrd Kunder 2007):

Üks hommiku varakult läinud vanem tüttar aeda juure piima ära kallama. Kui ta aga aeda ukse lahti tegi, veerenud ilus kuldmuna aeda põrmandall [---] põrmandall aga tulnud munast ilus sirge noor mees ja jäänud tütruku ette seisma ja teda omale kaasaks kauplema.

H II 46, 281/8 < Haljala khk, Vihula v - Leena Pruul (1894), ATU 312 (vt EMj I: 1 2009: 121-123)

Muinasjutus "Laibasööja” (ATU 363) on tüdruk nõus minema vaid kuldninaga mehele, nii saabubki just selline kosilane ja tüdruk on sunnitud oma lubadust täitma. Teel aga selgub, et tegemist on deemonliku olendiga, kes käib surnuid söömas:

Ennevanast elanud üks õige ilus ja uhke tüdruk. Kosilasi käinud iga päev karjana, aga keegi pole tüdrukule meeldinud, sest igaühel olnud ju loomulik, lihast nina, kuna aga tüdruk kuldninaga oli otsinud.

E 28680/3 (1) < Jämaja khk - Andrei Kuldsaar < K. Matsalo (1896), ATU 363 (vt EMj I: 1 2009: 284)

Huvitava paralleelina moodustab siinkohal laulutüüp "Kuldnaine", kus mees (sepp) valmistab endale kuldse naise. Muinasjutu kuldse ninaga mees ja regilaulu kuldnaine on oma olemuselt muidugi erinevad, kuid nad mõlemad tähistavad teatud mõttes ideaalse kaaslase otsingut (vt ka Ehin 2002: 66-67; Jaago 1993).

\section{Kokkuvõtteks}

Vaadates värvisõnade kasutust eesti imemuinasjuttudes võib öelda, et vähemalt osal neist paistab olevat tähenduslikum roll kui pelgalt välimust kirjeldaval epiteedil. Ehk teisisõnu ei saa päris nõustuda Max Lüthi seisukohaga muinasjutust kui ilma värvita maailmast. Kahtlemata on Lüthil õigus selles osas, et süžee seisukohalt ei muuda värvi nimetamine või selle puudumine midagi. Kuid tuleb tõdeda, et tegelast, olendit või eset kirjeldav värvus ei iseloomusta üksnes selle välist külge, vaid võib anda vihjeid kirjeldatu olemuse kohta ning loob lisatähendusi. 
Muinasjuttudes esinevate värvuste sümboolne tähendus kattub suures osas sellega, mis neil on rahvausundis ja regilaulus. Teistest värvustest tähenduslikumad on must ja valge, punane ja sinine. Muinasjuttudes on olulisel kohal ka hall ja kuldne.

Lisaks füüsilisele kirjeldusele antakse värvusega edasi tegelase või objekti sisemisi väärtusi ning sageli ka nende imelisust ja ebatavalisust. Must ja valge moodustavad vastandpaari, sümboliseerides head ja halba, ilu ja inetust, elu ja surma. Need tähendused jäävad neile alles ka omaette esinedes. Punane tähistab tervist, fertiilsust ja ilu ning esineb seetõttu enamasti noore naise kirjeldustes. Sel moel vastandub see mustale kui surma ja inetuse väljendajale, ja langeb kokku või täiendab valgele omistatavaid tähendusi. Samas võib punane vastanduda ka valgele, omandades sel juhul pigem negatiivse tähenduse. Kuldne ja teised metallid annavad edasi objekti imelisust või selle väärtuslikkust, samuti võivad vihjata kuldeseme omaniku sisemisele väärtusele. Hall on aga elutarkuse väljendaja või maskeerimisvärv, mis justkui püüaks varjata imelist argise taha.

Mitmesuguste assotsiatsioonide loomise ja hinnangute väljendamise vahendina on värvus kahtlemata väga oluline.

\section{Tänuavaldus}

Artikli valmimist on toetanud Haridus- ja Teadusministeeriumi uurimisprojektid IUT 22-4 "Folkloor kultuurilise kommunikatsiooni protsessis: ideoloogiad ja kogukonnad”, IUT 2-43 “Traditsioon, loovus ja ühiskond: vähemused ja alternatiivsed diskursused" ja Euroopa Liit Euroopa Regionaalarengu Fondi kaudu (Eesti-uuringute Tippkeskus - CEES).

\section{Kommentaarid}

1 [---] Ma lää mustale mehele / meesi musta meeli tarka / mees musta tegi tareta / meeli kati katusida / mure muida hoone'eida. E 52492 (47) < Karksi khk - Jaak Kivisäk (1893), laulutüüp "Hää mees" (Eesti regilaulude andmebaas http://www.folklore.ee/ regilaul/andmebaas/).

2 Dualistlik maailmatunnetus on läänelikus kultuuris sügavalt juurdunud. Juba antiigist alates on mõtiskletud vastandite mees-naine, keha-vaim ning loodus ja kultuur üle (Jorgensen 2013a: 51). Ka folkloristika lähtub oma käsitlustes sageli duaalsusest. Alan Dundes rõhutab, et binaarsed opositsioonid ei ole omased üksnes müüdile (millele osutab C. Lévi-Strauss), vaid ka muinasjutule (V. Propp) ning teistele folkloorižanridele. Vastandusele tugineb nii Axel Olriki eepilistes seadustes välja toodud kontrasti seadus (Dundes 2002: 140-152) kui ka Vladimir Proppi strukturalistlik muinasjututeooria, mille põhikomponendiks on 'puudus-puudus kõrvaldatud' ning 
Benkt Holbeki paradigmaatiline tegelaste omavahelisi suhteid näitav mudel (meesnaine, kõrge-madal, noor-täiskasvanu) (vt Jorgensen 2013a: 54-55).

3 Arhiivitekstide näited esitan siin ja edaspidi võimalikult originaalitruult, olen vajadusel ühtlustanud kirjaviisi ja kohendanud interpunktsiooni.

${ }^{4}$ Näib, et selles jututüübis on härja valge värvus kinnistunud ennekõike M. J. Eiseni "Kuningajuttudes" ilmunud loo "Hansust poeg ja valge härg" mõjul (vt Eisen 1906, $\mathrm{nr} 12)$.

5 Vt H II 27, 447/65 (3) < Palamuse khk, Luua - Mart Uus (1888).

6 Vt ERA II 286, 244 (223) < Setomaa, Petseri v, Lääpä k < Meremäe v, Triginä k - Ello Kirss < Ode [Jevdokia] Umblōja, snd 1880 (1940).

7 Tulemus, milleni Jorgensen on jõudnud, on ennekõike seotud uurimuse aluseks olnud materjaliga (230 muinasjututeksti). Ta kasutab trükis avaldatud jutukogumikke, mis sisaldavad nii kirjanduslikke (nt vennad Grimmid) kui ka rahvapäraseid tekste. Seega on tema materjal piiratud kindlate jutusüžeedega, mida tuleb uurimuse tulemusi analüüsides kindlasti arvestada.

8 Nt E 25224/9 (3) < Jämaja khk - Andrei Kuldsaar < Miina Kivisaar (1896); S 26273/85 (21) < Setomaa, Vilo v, Molnika k - Viktor Ruusamägi < Anastasia Paloots (1930).

9 Aga see hall nõder vanamees, keda vaene laps ja talutüttar oli vihelnud ei olnud kee muu kui Jumal ise (ERA II 198, 370/4 (10) < Helme khk - Aleksander Wahlberg (kirja pandud ajavahemikul 1860-80), arhiivi toonud Edur Tasa Nõost (1940), ATU 480).

${ }^{10}$ Surm ja suremine ei ole muinasjutus sageli lõplik, vaid seotud mingisuguse teisenemisega. Selle käigus võib muutuda tegelase kuju (inimtegelane muutub loomaks) või tegutsemise sfäär (liikumine teise ilma), harva tähendab see eksistentsi lõppu (vt Röhrich 1984: 133).

${ }^{11}$ Vt H II 3, 355/68 < Vastseliina khk - Hindrik Prants (1888), ATU $303+550$.

${ }^{12}$ E 2686/711 < Narva 1 - August Valts (1893), ATU $314+300$.

${ }^{13}$ H II 18, 325/30 (2) < Pöide khk, Uuemõisa v - Johann Trull (1888), ATU 675.

${ }^{14}$ EÜS VII 2121/34 (324) < Väike-Maarja khk, Porkuni v, Piisupi k - Voldemar Rosenstrauch; Peeter Penna < Hans Aberthal, 50 a (1910), ATU $313+400+325$.

${ }^{15}$ Vt E 2620/4 < Narva l - Friedrich Valts (1893), ATU 363.

${ }^{16}$ ERA II 198, 370/4 (10) < Helme khk - Aleksander Wahlberg (kirja pandud ajavahemikul 1860-80), arhiivi toonud Edur Tasa Nõost (1940), ATU 480).

${ }^{17}$ Vt H II 27, 859/63 (2) < Pilistvere khk < Kodavere khk - J. Käär (1888), ATU 328 + 327A; sama: EMj I: 1 2009: 234-235.

${ }^{18}$ Vt H I 10, 723/9 (1) < Setomaa, Pankjavitsa (Pantkavitsa) v, Jankino (Tsilli) k Friedrich Treijal (1897), ATU 531 + 327B; sama: EMj I: 2 2014: 167-176.

\section{Allikad}

Eesti Rahvaluule Arhiivis asuvad rahvaluulekogud:

E - Matthias Johann Eiseni rahvaluulekogu

EKmS - Eesti Kirjameeste Seltsi rahvaluulekogu 
ERA - Eesti Rahvaluule Arhiivi rahvaluulekogu

EÜS - Eesti Üliõpilaste Seltsi rahvaluulekogu

$\mathrm{H}$ - Jakob Hurda rahvaluulekogu

S - Samuel Sommeri setu vanavarakogu

Eesti regilaulude andmebaas http://www.folklore.ee/regilaul/andmebaas/

\section{Kirjandus}

Agirel, Seyfi 2009. Colour Symbolism in Turkish and Azeri Folk Literature. Folklore 120, lk 92-101 (doi: 10.1080/00155870802647858).

Apo, Satu 1986. Ihmesadun rakenne. Juonien tyypit, pääjaksot ja henkilõasetelmat Satakuntalaisessa kansansatuaineistossa. Suomalaisen Kirjallisuuden Seuran Toimituksia 446. Helsinki: Suomalaisen Kirjallisuuden Seura.

Baker-Sperry, Lori \& Grauerholz, Liz 2003. The Pervasiveness and Persistence of the Feminine Beauty Ideal in Children's Fairy Tales. Gender and Society 17 (5), lk 711-726 (doi: 10.1177/0891243203255605).

Dundes, Alan 2002. Binaarne opositsioon müüdis: pilk Proppi ja Lévi-Straussi väitlusele. Valk, Ülo \& Lepp, Evelin (toim). Kes on rahvas? Valik esseid folkloristikast. Tartu: Varrak, lk 140-152.

Ehin, Kristiina 2002. Mehed teevad naist: regilaulu "Kuldnaine" tähenduskontuure. Ariadne Lõng 1/2. Nais- ja meesuuringute ajakiri, III aastakäik. Tallinn, lk 62-72.

Eisen, Matthias Johann 1906. Kuninga-jutud. Kuningatest, kuninga poegadest, kuninga tütardest ja kuninga tütarde wäimeestest. Rahwa suust kokkukorjatud. 2., täiendatud trükk. Tartu: Hermann.

EMj I: 12009 = Järv, Risto \& Kaasik, Mairi \& Toomeos-Orglaan, Kärri (koost, toim). Eesti muinasjutud I: 1. Imemuinasjutud. Tartu: Eesti Kirjandusmuuseumi Teaduskirjastus.

EMj I: 22014 = Järv, Risto \& Kaasik, Mairi \& Toomeos-Orglaan, Kärri \& Annom, Inge (koost, toim). Eesti muinasjutud I: 2. Imemuinasjutud. Tartu: Eesti Kirjandusmuuseumi Teaduskirjastus.

Hiiemäe, Mall 1999. Aabitsakuke usundilisest taustast. Forseliuse Sõnumid 6. Tartu, lk 17-20.

Hiiemäe, Reet 1997. Eesti katkupärimus. Eesti muistendid. Mütoloogilised haigused I. Monumenta Estoniae Antiquae II. Tartu: EKI Eesti Folkloristika osakond, EKM Eesti Rahvaluule Arhiiv.

Holbek, Bengt 1987. Interpretation of Fairy Tales. Danish Folklore in a European Perspective. FF Communication No. 239. Helsinki: Suomalainen Tiedeakatemia, Academia Scientiarum Fennica.

Hurley, Dorothy L. 2005. Seeing White: Children of Color and the Disney Fairy Tale Princess. The Journal of Negro Education 74 (3), lk 221-232.

Jaago, Tiiu 1993. Kuldnaine. Tartu: Tartu Ülikooli eesti ja võrdleva rahvaluule õppetool. 
Jaago, Tiiu 1997. Mis sealt tõuseb, soost sinine, soost sinine, maast punane? Sinise ja punase võimalikust tähendusest regilaulus. Mäetagused 5, lk 54-72 (http://www.folklore. ee/tagused/nr5/pdf/tiiu.pdf - 12. juuli 2016, doi: 10.7592/MT1997.05.tiiu).

Jaago, Tiiu 2016. Punane regilaulus: sõnad ja vormelid. Mäetagused 64, lk 9-34 (http:// dx.doi.org/10.7592/MT2016.64.jaago).

Jason, Heda 1977. Ethnopoetry - Form, Content, Function. Forum Theologiae Linguisticae 11. Bonn: Linguistica Biblica Bonn.

Jorgensen, Jeana 2013a. The Black and the White Bride: Dualism, Gender, and Bodies in European Fairy Tales. Journal of History and Cultures 3, lk 49-71 (http://digitalcommons. butler.edu/facsch_papers/679 - 12. juuli 2016).

Jorgensen, Jeana 2013b. Embodiment, Representation, and Perception in Fairy-Tale Scholarship: Connecting the Written Body and the Writing Body. Kulasalu, Kaisa \& Päll, Lona \& Rumm, Kaija (koost). Kogemus, taju, keha: uurimusi noorteadlastelt. Vanavaravedaja 8, Tartu: Tartu NEFA Rühm, lk 184-201.

Kalits, Vilve 1997. Kihnu ajaloost, majandusest ja kultuurist. Kõiva, Ottilie \& Rüütel, Ingrid (koost ja toim). Vana kannel VII: 1. Kihnu regilaulud. Monumenta Estoniae Antiquae I. Tartu: Eesti Kirjandusmuuseum, lk 12-34.

Kalmre, Eda 1989. "Tuhkatriinu” (AT 510A) eesti rahvatraditsioonis. Ertis, Eduard \& Hiiemäe, Mall \& Kalmre, Eda (toim). Paar sammukest eesti kirjanduse uurimise teed XII. Uurimusi Jakob Hurda 150. sünniaastapäevaks. Tallinn: Eesti Raamat, lk 137-147.

Kunder, Juhan 2007 (1885). Järv, Risto \& Kaasik, Mairi \& Toomeos-Orglaan, Kärri (toim). Eesti muinasjutud. Kommenteeritud väljaanne. [Võrguteavik.] Tartu Ülikool (http://www.folklore.ee/UTfolkl/mj/kunder/ - 12. juuli 2016).

Kõivupuu, Marju 1999. Rahvaarstid. Noor ja vana Suri Võrumaalt (http://www.folklore. ee/pubte/rahvaarstid/ - 12. juuli 2016).

Kõivupuu, Marju 2008. Rahvameditsiin. Viires, Ants \& Vunder, Elle (koost ja toim). Eesti rahvakultuur. 2., täiendatud trükk. Tallinn: Eesti Entsüklopeediakirjastus, lk 363-378.

Lüthi, Max 1982. The European Folktale: Form and Nature. Bloomington \& Indianapolis: Indiana University Press.

Paal, Piret 2014. Halltõbi. Eesti muistendid. Mütoloogilised haigused II. Monumenta Estoniae Antiquae II. Tartu: Eesti Kirjandusmuuseumi Teaduskirjastus.

Peegel, Juhan 1997. Kuld on jäänud jälgedesse. Regivärsi keelest ja poeetikast. Tartu: Eesti Kirjandusmuuseum.

Roll, Tiiu 1985. Värvinimetused ja nende kujundiline osa regivärsilises pulmalaulus. Probleeme eesti regilaulude alalt. Tartu Riikliku Ülikooli Toimetised 699. Töid eesti filoloogia alalt X. Tartu, lk 34-58.

Röhrich, Lutz 1984. The quest of meaning in folk narrative research. ARV Scandinavian Yearbook of Folklore 40. Stockholm, lk 127-138.

Sarapik, Virve 1994. Valge ja must. Oras, Janika (toim). Loomine. Pro Folkloristica II. Tartu, lk 37-46.

Sarapik Virve 1997. Red: the Colour and the Word. Folklore: Electronic Journal of Folklore 3, lk 93-130 (doi: 10.7592/FEJF1997.03.red). 
Sarapik, Virve 1998. Punane. Sõna ja värv. Kõiva, Mare \& Kalda, Mare (toim). Artikleid usundi ja kombeloost. Sator 1. Tartu: Eesti Keele Instituudi rahvaluule töörühm, lk 7-37 (http://www.folklore.ee/rl/pubte/ee/sator/ - 12. juuli 2016).

Sohberg, Martin 1876. Viies Eesti juttutooja. Vanad ennemuistesed juttud. M. Sohberg kirja pannud. Viljandi: F. Feldt.

Sutrop, Urmas 2011. Eesti keele värvussõnavara arengu põhijooni. Uusküla, Mari \& Sutrop, Urmas (koost ja toim). Värvinimede raamat. Töid antropoloogilise ja etnolingvistika vallast 5. Tallinn: Eesti Keele Sihtasutus, lk 397-420.

Sutrop, Urmas 2016. Värvinimed ja värvid vendade Grimmide muinasjutu "Lumivalguke" variantides. Mäetagused 64, lk 57-68 (http://dx.doi.org/10.7592/MT2016.64.sutrop).

Toomeos-Orglaan, Kärri 2013. Gender Stereotypes in Cinderella (ATU 510A) and The Princess on the Glass Mountain (ATU 530). Journal of Ethnology and Folkloristics 7 (2), lk 49-64 (http://www.jef.ee/index.php/journal/article/view/142 - 12. juuli 2016).

Valk, Ülo 1998. Allilma isand: kuradi ilmumiskujud eesti rahvausus. Eesti Rahva Muuseumi sari 1. Tartu: Eesti Rahva Muuseum.

Vaz da Silva, Francisco 2007. Red as Blood, White as Snow, Black as Crow: Chromatic Symbolism of Womanhood in Fairy Tales. Marvels \& Tales 21 (2), lk 240-252.

Voolaid, Piret 2016. Värvisõnad ja värvisümbolid eesti mõistatuste alaliikides. Mäetagused 64, lk 69-98 (http://dx.doi.org/10.7592/MT2016.64.voolaid).

\section{Summary}

\section{What is the colour of fairy tales?}

Kärri Toomeos-Orglaan

Keywords: beauty, corporeality, colour symbolism, fairy tale

The article presents a research of the usage of colours in Estonian fairy tales and the associations that are created by means of colours. The topic of colour usage also includes the aspect of corporeality that generates a critical discussion on the presentation of a woman in fairy tales. The symbolical meanings of different colours in fairy tales largely overlap with their meanings in folk belief and runo songs. The colours that are particularly meaningful are black, white, and red. Also, such colours as grey and gold occupy special places in fairy tales. In addition to physical description, colours are used to present characters' or objects' inner values, also expressing the way they differ from the ordinary, or hinting at the magical qualities they may possess.

Black and white form a pair of opposites, symbolising good and evil, beauty and ugliness, life and death. Those meanings remain with them also in case one is being used without the other. The colour red represents health, fertility, and beauty; that is why it is frequently used in the descriptions of women. At the same time, the colour red can be used as an opposite to white, having in this case a negative meaning.

Gold and other metals show the object's magical characteristics, but at the same time also its value. Possessing a golden object can also hint at the owner's high moral values. The colour grey represents wisdom but it can also be seen as a colour that disguises magical as ordinary. 